\title{
PENGARUH PENINGKATAN KAPASITAS MESIN TERHADAP WAKTU KERJA PENYARADAN KAYU HUTAN ALAM DENGAN SISTEM MESIN PANCANG TARIK DI PT RATAH TIMBER
}

\author{
Ruspita Sihombing \\ Staf Pengajar Jurusan Teknik Mesin, Politeknik Negeri Samarinda \\ email: Ruspita.sihombing@yahoo.co.id
}

\begin{abstract}
Abstrak
Pemanenan kayu ramah lingkungan (Reduced Impact Timber Harvesting/RITH) menjadi indikator yang paling penting dalam pengelolaan hutan. Metode pemanenan kayu yang berdampak rendah mampu mengurangi kerusakan ekosistem hutan alam produksi. Salah satu alat kerja pemindah (penarik) kayu hutan yang lebih ramah lingkungan adalah menggunakan Mesin Pancang Tarik. Prinsip kerja mesin ini tetap berada pada tempat tertentu, sedangkan kayu ditarik menggunakan sling atau kabel. Penelitian tentang Pengaruh Peningkatan Kapasitas Mesin Terhadap Waktu Kerja Penyaradan Kayu Hutan Alam dengan Sistem Mesin Pancang Tarik (Monocable Winch) di PT. Ratah Timber ini dikaji dari, (1) Aspek waktu kerja, yaitu seberapa besar pengaruh peningkatan kapasitas mesin dari 20PK menjadi 26PK terhadap lamanya penyaradan. Metode penelitian yang digunakan adalah kombinasi antara kuantitatif dan kualitatif, yang dilakukan pada proses penyaradan kayu dengan menggunakan Mesin Pancang Tarik 20PK dan 26 PK, berfokus pada: (1) Tofografi areal hutan, dimaksudkan untuk melihat fenomena penyaradan; (2) Mencatat waktu kerja murni dan waktu umum dengan menggunakan mesin $20 P K$ dan $26 \mathrm{PK}$ pada proses penyaradan kayu pada kelerengan $\leq 40 \%$.

Hasil yang diperoleh dari penelitian ini menunjukkan, bahwa pengaruh peningkatan kapasitas mesin terhadap waktu kerja Penyaradan Kayu Hutan Alam dengan Sistem Mesin Pancang Tarik (Monocable Winch) di PT. Ratah Timber pada kelerengan $\leq 40 \%$ tidak significan.
\end{abstract}

Kata kunci: Mesin Pancang Tarik, Penyaradan dan Waktu Kerja

\section{PENDAhuluan}

Sekarang ini kayu sangat sulit diperoleh, sehingga untuk mendapatkan kayu kita harus melalui perjalanan yang cukup panjang dan melelahkan. Dimana seperti yang kita ketahui Indonesia memiliki areal hutan yang tofografinya curam dan berawa dibutuhkan cara pemanenan kayu yang ramah lingkungan.

Pemanenan kayu yang dilaksanakan selama ini bersifat konvensional di mana pemanenan kayu dilaksanakan tanpa 
Ruspita Sihombing, Pengaruh Peningkatan Kapasitas Mesin Terhadap Waktu Kerja Penyadaran Kayu Hutan Alam Dengan Sistem Mesin Pancang Tarik Di PT. Ratah Timber Company

perencanaan yang baik, teknik pelaksanaan yang buruk dan lemahnya pengawasan yang menyebabkan kerusakan lingkungan hutan (Elias 1997; Dykstra, D.P. and R. Heinrich, 1996). Kerusakan hutan juga banyak diakibatkan cara kerja produksi yang kurang ramah lingkungan, misalnya; penggunaan alat berat (bulldozer/skider) di hutan yang kondisi tanahnya kurang stabil untuk penggunaan alat tersebut.

Hasil penelitian sebelumnya, sistim penyaradan kayu dengan sistim Mono Kabel daya 20 PK dapat menyarat sebesar 8 ton, menimbulkan kerusakan yang lebih kecil terhadap singkapan tanah dan tegakan tinggal. Pencemaran lingkungan lebih kecil dikarenakan penggunaan bahan bakar lebih sedikit sehingga menghasilkan emisi karbon da ri bahan bakar dapat dikurangi. Selain daripada itu pengoperasian dan perawatan lebih murah dan melibatkan masyarakat (Ruslim, et al., 2011).

Oleh karena itu, adalah perlu untuk merencana dan menghitung waktu kerja mesin Pancang Tarik dengan menaikkan daya dari 20PK menjadi 26PK. Selanjutnya dari hasil pengamatan dilapangan akan diperoleh seberapa besar peningkatan waktu kerja diakibatkan peningkatan kapasitas mesin dari 20PK menjadi $26 \mathrm{PK}$ pada proses penyaradan tersebut. Hal inilah yang menarik perhatian penulis untuk mengangkat judul "Pengaruh Peningkatan Kapasitas Mesin Terhadap Waktu Kerja Penyaradan Kayu pada Hutan Alam dengan Sistem Mesin Pancang Tarik (Monocable Winch) di PT. Ratah Timber".

\section{TINJAUAN PUSTAKA}

Sanyoto (1976), secara garis besar membagi waktu kerja menjadi 2 bagian, yaitu:

1. Waktu Umum Waktu umum adalah waktu yang dibutuhkan untuk melakukan perbuatan yang tidak mempunyai hubungan langsung dengan perbuatan kerja produktif akan tetapi perlu guna kelancaran suatu pekerjaan. Waktu umum ini terbagi atas waktu diam, waktu hilang dapat dihindarkan, waktu hilang tidak dapat dihindarkan, waktu istirahat dan waktu pribadi.

2. Waktu kerja murni

Waktu kerja murni adalah waktu kerja yang dibutuhkan untuk melaksanakan pekerjaan pokok yang merupakan perbuatan kerja yang produktif. Waktu Kerja Murni terbagi atas persiapan menyalakan mesin,membersihkan jalan kayu, meruncingkan ujung kayu, menarik sling, memasang sling,menyambung sling, menarik kayu, mengatur sling, melepas sling, dan menggulung sling.

Penelitian waktu dan analisis metode kerja pada dasarnya akan memusatkan perhatian tentang bagaimana suatu macam pekerjaan dengan mengaplikasikan prinsip dan teknik pengaturan cara kerja yang optimal, sehingga diperoleh alternatif metode pelaksanaan kerja yang optimal. Artinya, akan diperoleh alternatif pelaksanaan kerja yang dianggap memberikan hasil yang paling baik efektif dan efisisen. Wignjosoebroto, (1989) dan Sanyoto (1976), menyatakan bahwa pengukuran kerja adalah suatu cara untuk menyelidiki faktor-faktor yang mempengaruhi presentasi kerja. Selanjutnya, Mulyono (1986), menyatakan bahwa pengukuran kerja adalah penerapan waktu bagi seorang pekerja yang dianggap memiliki sifat kemampuan jasmani yang diperlukan yang mempunyai kecerdasan dan pendidikan yang ditentukan serta telah memperoleh keterampilan dan pengetahuan yang cukup untuk melaksanakan pekerjaan yang bersangkutan sehingga dapat menyelesaikan pekerjaan tertentu pada tingkat profesi yang telah ditetapkan. 
Vol. 4, No. 2, April 2017

Sanyoto (1976), juga menyatakan bahwa metode pengukuran kerja terdiri dari beberapa cara kerja, antara lain:

1. Metoda Non Stop

Pengukuran waktu kerja menggunakan sebuah stopwatch, selama pengamatan stopwatch dibiarkan hidup terus. Lamanya waktu kerja untuk setiap elemen kerja adalah selisih waktu antara dua elemen kerja yang berdekatan, sistem pengukuran ini dapat dilaksanakan oleh seorang pengukur dan hanya dapat mengamati satu objek penelitian.

2. Metoda Nol Stop

Pengukuran waktu menggunakan tiga buah stopwatch. Stopwatch pertama posisi jarumnya menunjukan angka nol, stopwatch kedua jarumnya berada disembarang tempat dan stopwatch ketiga posisi jarumnya bergerak. Pengukuran waktu dimulai dengan menekan semua tombol stopwatch sehingga jarum pertama stopwatch bergerak, stopwatch kedua kembali ke anggka nol dan stopwatch ketiga berhenti. Pada penekanan kedua, jarum stopwatch ketiga kembali ke anggka nol, dan pada penekanan ketiga stopwatch ketiga bergerak untuk menunjukan waktu kerja elemen ketiga. Lama waktu untuk tiap elemen kerja dapat dibaca pada stopwatch kedua dan ketiga. Dalam metode ini pengukur hanya dapat mengawasi satu objek penelitian saja.

3. Metode Multi Moment

Pengukuran kerja menggunakan satu buah stopwatch, selama pengamatan stopwatch dibiarkan hidup. Pencatatan waktu kerja dari elemen kerja dilakukan pada setiap interval waktu tertentu dengan memberi satu titik atau garis pada kolom elemen kerja bersangkutan. Sistem ini dapat mengamati lebih dari satu objek.

Sistim penyaradan dengan menggunakan kabel dimana mesin pancang tarik yang stationer sehingga log yang disarad menggunakan kabel atau sling terkumpul disuatu tempat dengan mesin penyarad. Seperti gambar dibawah ini menunjukkan penempatan mesin Monocabel di hutan.
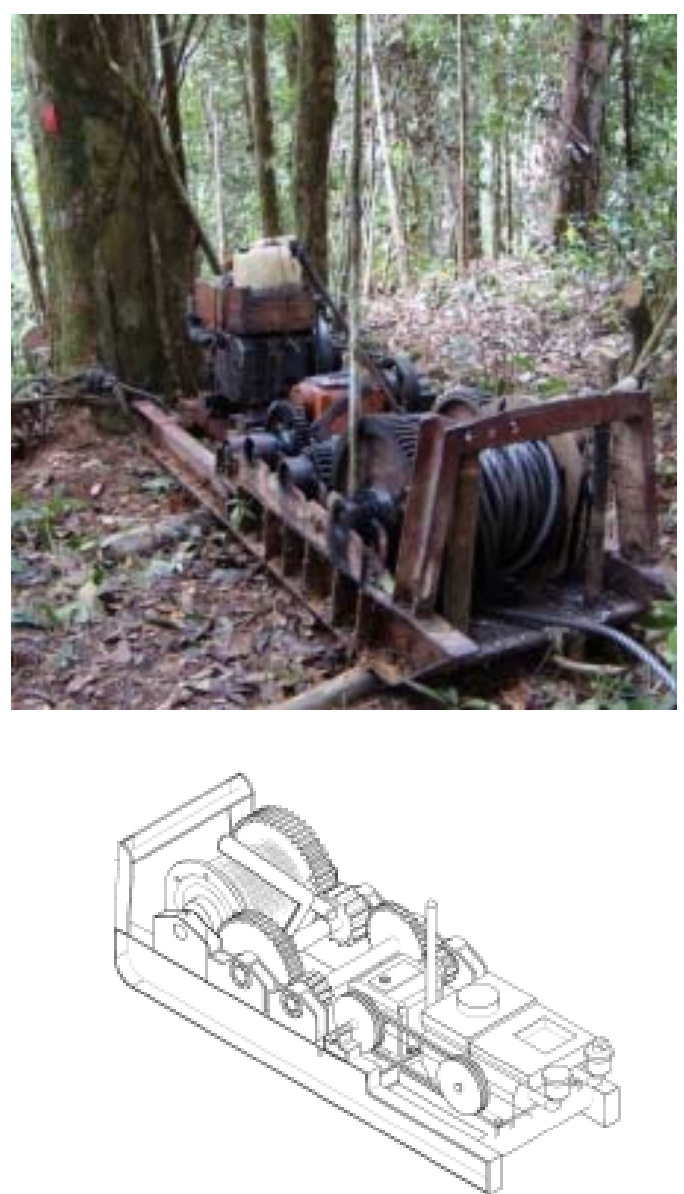

Gambar 1.

Mesin Pancang Tarik (Mesin Monocabel) 
Ruspita Sihombing, Pengaruh Peningkatan Kapasitas Mesin Terhadap Waktu Kerja Penyadaran Kayu Hutan Alam Dengan Sistem Mesin Pancang Tarik Di PT. Ratah Timber

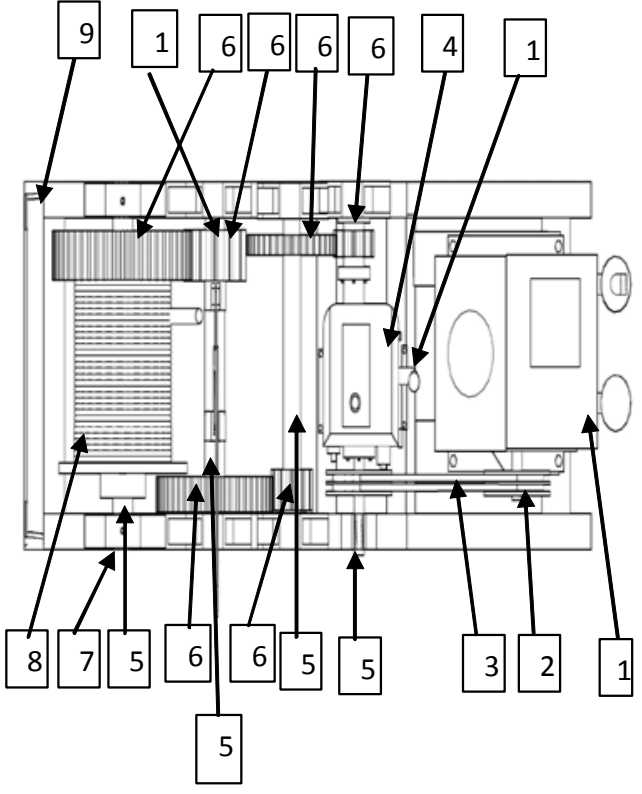

Gambar 2.

Pandangan Atas Mesin Pancang Tarik

\begin{tabular}{|l|l|c|}
\hline NO & NAMA BAGIAN & JUMLAH \\
\hline 1 & Mesin Penggerak & 1 \\
\hline 2 & Pully & 2 \\
\hline 3 & V-Belt & 2 \\
\hline 4 & Gear Box & 1 \\
\hline $5 \mathrm{a}$ & Poros 1 & 1 \\
\hline $5 \mathrm{~b}$ & Poros 2 & 1 \\
\hline $5 \mathrm{c}$ & Poros 3 & 1 \\
\hline $5 \mathrm{~d}$ & Poros 4 & 1 \\
\hline 6a & Roda Gigi 12 & 1 \\
\hline $6 \mathrm{~b}$ & Roda Gigi 38 & 1 \\
\hline $6 \mathrm{c}$ & Roda Gigi 12 & 1 \\
\hline $6 \mathrm{~d}$ & Roda Gigi 47 & 1 \\
\hline $6 \mathrm{e}$ & Roda Gigi 13 & 1 \\
\hline $6 \mathrm{f}$ & Roda Gigi 50 & 1 \\
\hline 7 & Bantalan & 8 \\
\hline 8 & Sling & 1 \\
\hline 9 & Rangka & 1 \\
\hline
\end{tabular}

\section{METODE PENELITIAN}

\section{LOKASI DAN WAKTU PENELITIAN}

Penelitian dilaksanakan pada bulan November 2013 di PT. Ratah Timber Company (RTC) terletak pada $114^{0} 55^{\prime}-115^{0}$ 30 ' Bujur Timur dan $0^{02} \mathrm{LS}-0^{0} 15$ 'LU berada dalam wilayah kecamatan Long Hubung dan Kecamatan Laham, kabupaten Mahakam Ulu provinsi Kalimantan timur. Jenis tanah berupa Kamp Mamahaq Teboq Kabupaten Mahakam Ulu. Kelerengan areal kerja sebesar - $1+71,9 \%$ tergolong datar hingga landai. Jenis tanah terdiri dari tiga jenis tanah, yaitu podsolik merah kuning, latososl dan alluvial. Tipe iklim menurut sistem klasifikasi Schidmat dan Fergusson (1993), iklim di areal kerja IUPHHK PT RATAH TIMBER COMPANY termasuk iklim sangat besar atau tipe A dengan jumlah bulan basah adalah 12 bulan (nilai $\mathrm{Q}=0 \%$ ). Tegakan pada areal penelitian adalah tegakan Dipterocarpaceae yang memiliki kerapatan yang lebih besar antara 493 pohon/3ha dan jenis pohon lain sebanyak 314 pohon 3ha (untuk pohon berdiameter $20 \mathrm{~cm}$ ke atas). Tumbuhan bawah memiliki kerapatan jarang.

\section{OBJEK PENELITIAN}

Objek yang diamati pada penelitian ini adalah mengukur waktu murni dan waktu umum guna mengetahui waktu kerja atau lamanya menyarat kayu.

\section{PERALATAN}

\section{Peralatan pendukungnya adalah :}

1. Mesin Pancang Tarik

2. Stopwatch, untuk mengukur waktu setiap elemen kerja penyaradan

3. Kompas, untuk mengukur arah rentang kabel

4. Clinometer, untuk mrngukur kemiringan lapangan

5. Altimeter, untuk mengukur ketinggian tempat diatas permukaan laut 
Vol. 4, No. 2, April 2017

6. Kamera dan roll film, untuk dokumentasi

7. Alat tulis

\section{ANALISA DATA}

Setekah pengambilan data selesai, dapat dilakukan;

1. Menghitung Waktu kerja murni antara lain; persiapan menyalakan mesin,membersihkan jalan kayu, meruncingkan ujung kayu, menarik sling, memasang sling,menyambung sling, menarik kayu, mengatur sling, melepas sling, dan menggulung sling. Waktu Umum antara lain; waktu diam, waktu hilang dapat dihindarkan, waktu hilang tidak dapat dihindarkan, waktu istirahat dan waktu pribadi.

2. Menghitung waktu kerja penyaradan dengan rumus:

Waktu Kerja = Waktu Kerja Murni + Waktu Umum

\section{HASIL DAN PEMBAHASAN}

Waktu Peyaradan Kayu, Volume, Jarak Sarad dan Produktivitas Penyaradan Kayu pada kelerengan $\leq 40 \%$ (Datar Curam)

Waktu kerja penyaradan dibagi dalam dua bagian yaitu waktu kerja murni (Persiapan menyalakan mesin, Membersihkan jalan kayu, Meruncingkan ujung kayu Meruncingkan ujung kayu,
Menarik sling, Memasang sling, Menyambung sling, Menarik kayu, Mengatur sling, Melepas sling, Menggulung sling) dan waktu umum (waktu diam, waktu hilang dapat dihindarkan, waktu hilang tidak dapat dihindarkan, waktu istirahat dan waktu pribadi).

Berdasarkan hasil pengukuran panjang, diameter pangkal dan ujung kayu, jarak sarad dan waktu penyaradan pada kelerengan $\leq 40 \%$ (ada 2 macam yaitu kelerengan mendaki $(+\leq 40 \%)$ yaitu posisi mesin diatas, kayu dibawah atau arah sarat kayu mendaki dan kelerengan menurun ( $\leq 40 \%$ ) yaitu posisi mesin dibawah, kayu diatas atau arah sarat kayu menurun) diolah dan dibuat tabel sebagai berikut;

Berdasarkan hasil pengukuran elemen waktu kerja murni dan elemen waktu umum di plot penelitian dengan menggunakan mesin pancang tarik $20 \mathrm{PK}$ dan 26 PK di PT Ratah Timber Company dapat dilihat pada tabel tentang Total RataRata Waktu Kerja Murni, Waktu Umum dan Waktu Kerja pada Kelerengan $\leq 40 \%$, yang selanjutnya dibuat grafik seperti di bawah ini.

Tabel 1.

Total Rata-Rata Waktu Kerja Murni, Waktu Umum dan Waktu Kerja pada Kelerengan $\leq$ 40\% (Datar-Curam) Mesin 20 PK dan Mesin 26 PK

\begin{tabular}{|l|c|c|}
\hline \multicolumn{1}{|c|}{ Waktu Kerja } & 20 PK (Jam) & 26 PK (Jam) \\
\hline Total rata-rata waktu kerja murni & 0,74 & 0,67 \\
\hline Total rata-rata waktu umum & 0,07 & 0,09 \\
\hline Total rata-rata waktu kerja & 0,81 & 0,76 \\
\hline
\end{tabular}


Ruspita Sihombing, Pengaruh Peningkatan Kapasitas Mesin Terhadap Waktu Kerja Penyadaran Kayu Hutan Alam Dengan Sistem Mesin Pancang Tarik Di PT. Ratah Timber Company

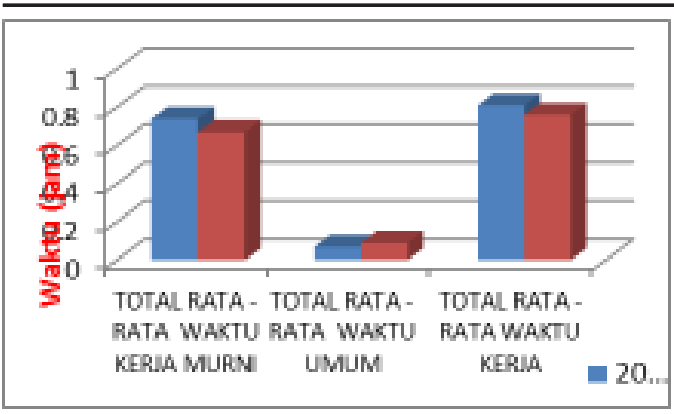

Gambar 2. Grafik Total Rata-Rata Waktu Kerja Murni, Waktu Umum dan Waktu Kerja Mesin 20 PK dan Mesin 26 PK pada Kelerengan $\leq 40 \%$ (Datar-Curam).

Sanyoto (1976), secara garis besar membagi waktu kerja menjadi 2 bagian, yaitu: Waktu kerja murni dan waktu umum, dengan kata lain

\section{Waktu Kerja $=$ Waktu Kerja Murni + Waktu Umum}

Pada Gambar 2, terlihat bahwa total rata-rata waktu kerja murni lebih besar dari pada total rata-rata waktu umum pada ke dua kapasitas mesin pada kegiatan penyaradan sistem monokabel dengan menggunakan mesin pancang tarik. Dari data Tabel 1. dapat diketahui persentase total rata-rata waktu kerja murni (\% Total Rata-Rata WKM) dan persentase total rata-rata waktu umum (\% Total Rata-Rata WU) seperti di bawah ini.

\section{Mesin 20PK}

a. $\quad \%$ Total Rata-Rata WKM $=\frac{0,74}{0,81} \mathrm{x}$

$$
100 \%=91,36 \%
$$

b. $\%$ Total Rata-Rata WU $=\frac{0,07}{0,81} \times$

$$
100 \%=8,64 \%
$$

2. Mesin 26PK

a. $\quad \%$ Total Rata-Rata WKM $=\frac{0,67}{0,76} \mathrm{x}$

$100 \%=88,16 \%$

b. $\%$ Total Rata-Rata WU $=\frac{0,09}{0,76} \mathrm{x}$

$$
100 \%=11,84 \%
$$

Selanjutnya, apabila persentase Waktu Kerja Murni lebih besar dari 80\%, maka proses penyaradan tersebut dinyatakan baik atau berhasil. Hasil perhitungan diatas menunjukkan \% WKM menggunakan mesin 20 PK dan mesin 26 PK lebih besar dari 80\% maka proses penyaradan tersebut produktip baik (Syamsi Ibnu, Sistim dan Prosedur Kerja 1994).

Berdasarkan Gambar 2. juga terlihat bahwa total rata-rata waktu kerja pada mesin kapasitas 20 PK lebih besar dibanding dengan kapasitas mesin 26 PK. Hal ini, disebabkan pada jarak sarad yang sama putaran mesin sama. Dengan kata lain, kecepatannya juga sama, tetapi kekuatan tarik pada kedua kapasitas mesin berbeda, sehingga menyebabkan kapasitas mesin yang besar (26 PK) kekuatan tariknya lebih besar sehingga dapat menyarad massa kayu yang lebih besar pula. Selain itu, gangguan tegakan tinggal pada plot penelitian menggunakan mesin 20 PK lebih besar dibanding dengan mesin 26 PK. Dengan demikian, berarti waktu kerja menggunakan mesin 20 PK lebih besar dibanding menggunakan mesin 26 PK. Namun, waktu umum pada mesin kapasitas 26 PK lebih besar dari pada waktu umum mesin kapasitas $20 \mathrm{PK}$.

Jika kita melihat Gambar 2. Grafik Total Rata-Rata Waktu Elemen Umum Mesin 20 PK dan Mesin 26 PK pada Kelerengan $\leq 40 \%$ (Datar-Curam) menunjukkan bahwa waktu elemen diam pada mesin 26 PK memakai waktu yang lebih lama (besar) sehingga menyebabkan 
total rata-rata waktu umum menggunakan mesin 26 PK lebih besar. Untuk mengindari kondisi seperti itu dibutuhkan pengawasan yang baik dari perusahaan dan keahlian dan ketekunan dari tim pekejra.

Untuk menguji apakah ada perbedaan rata-rata waktu penyaradan atau tidak, dari data waktu penyaradan kayu menggunakan mesin $20 \mathrm{PK}$ dan mesin $26 \mathrm{PK}$ dilakukan Uji t atau Independent Samples T Test seperti Tabel di bawah ini. varian yang sama, sehingga uji Independent Sampel T - test menggunakan Equal.

Dari tabel Independent Sampel T test didapat $\mathrm{t}-$ hitung sebesar 0,67 . Nilai $\mathrm{t}-$ tabel pada signifikansi pada uji dua sisi $(0,05$ :2) dengan derajat kebebasan 154 didapat $\mathrm{t}$ - tabel 1,98. Karena $\mathrm{t}$ - hitung $<\mathrm{t}$ - tabel berarti ho diterima, artinya tidak ada perbedaan antara waktu penyaradan menggunakan mesin $20 \mathrm{PK}$ dan mesin $26 \mathrm{PK}$ pada kelerengan $\leq 40 \%$.

\begin{tabular}{|c|c|c|c|c|c|}
\hline & $\begin{array}{c}\text { Kapasitas } \\
\text { mesin }\end{array}$ & $\begin{array}{c}\text { Jumlah } \\
\text { sampel }\end{array}$ & Rata-rata & $\begin{array}{c}\text { Simpangan } \\
\text { baku populasi }\end{array}$ & $\begin{array}{c}\text { Standar rata-rata } \\
\text { kesalahan }\end{array}$ \\
\hline \multirow{2}{*}{ Waktu } & 1,00 & 89 & 0,81 & 0,53 & 0,06 \\
\cline { 2 - 6 } & 2,00 & 67 & 0,76 & 0,44 & 0,05 \\
\hline
\end{tabular}

Keterangan; $\quad 1=$ Jenis Kapasitas Mesin 20PK

2 = Jenis Kapasitas Mesin 26PK

\begin{tabular}{|c|c|c|c|c|c|c|c|c|}
\hline & \multicolumn{2}{|c|}{$\begin{array}{c}\text { Uji } \\
\text { homogenitas } \\
\text { untuk } \\
\text { persamaan } \\
\text { varian data }\end{array}$} & \multicolumn{5}{|c|}{ t-test untuk persamaan rata-rata } \\
\hline & & \multirow[b]{2}{*}{$\mathrm{F}$} & \multirow[b]{2}{*}{ Sig. } & \multirow[b]{2}{*}{$\mathrm{t}$} & \multirow[b]{2}{*}{ df } & \multirow{2}{*}{$\begin{array}{l}\text { Sig. } \\
(2- \\
\text { ujung } \\
\quad)\end{array}$} & \multicolumn{2}{|c|}{$\begin{array}{c}95 \% \text { Interval } \\
\text { kepercayaan atas } \\
\text { perbedaan }\end{array}$} \\
\hline & & & & & & & $\begin{array}{c}\text { Terenda } \\
\mathrm{h}\end{array}$ & $\begin{array}{c}\text { Tertingg } \\
\text { i }\end{array}$ \\
\hline \multirow[t]{2}{*}{$\begin{array}{c}\text { Wakt } \\
\mathrm{u}\end{array}$} & $\begin{array}{l}\text { Persamaa } \\
\mathrm{n} \text { varian } \\
\text { terasumsi }\end{array}$ & 3,84 & $\begin{array}{c}0,05 \\
2\end{array}$ & $\begin{array}{c}0,6 \\
7\end{array}$ & 154 & 0,503 & $-0,10$ & 0,21 \\
\hline & $\begin{array}{l}\text { Persamaa } \\
\mathrm{n} \text { varian } \\
\text { tidak } \\
\text { terasumsi }\end{array}$ & & & $\begin{array}{c}0,6 \\
9\end{array}$ & $\begin{array}{c}152,8 \\
1\end{array}$ & 0,491 & $-0,10$ & 0,21 \\
\hline
\end{tabular}

Dari hasil uji levene's (homogenitas) didapat nilai $\mathrm{F}=3,84$ dan signifikansi 0,052 , dengan demikian 0,05 $2>0,05$ artinya Ho diterima. Selanjutnya, dapat disimpulkan bahwa jenis varian data waktu penyaradan antara menggunakan mesin $20 \mathrm{PK}$ dan mesin 26 PK pada kelerengan $\leq 40 \%$ memiliki 
Ruspita Sihombing, Pengaruh Peningkatan Kapasitas Mesin Terhadap Waktu Kerja Penyadaran Kayu Hutan Alam Dengan Sistem Mesin Pancang Tarik Di PT. Ratah Timber Company

\section{KESIMPULAN DAN SARAN \\ KESIMPULAN}

Dari hasil penelitian pengaruh peningkatan kapasitas mesin dari 20PK menjadi 26PK terhadap waktu kerja pada proses penyaradan kayu di PT. Ratah Timber disimpulkan sebagai berikut;

Berdasarkan Uji T-Test hasilnya menunjukkan non significant.

\section{DAFTAR PUSTAKA}

Elias, 1997. Bahan Kuliah Pemanenan Hasil Hutan Fakultas Kehutanan ,Institut Pertanian Bogor.

Elias, 1998. Kriteria Tingkat Kerusakan Tegakan Tinggal Akibat Kegiatan Penebangan Dan Penyaradan.

Erina Hertianti, 2005. Studi Penyaradan Kayu dengan Sistim Monokabel (Mesin Pancang) di Kampung Sungai Lunuq Kecamatan Tabang Kabupaten Kutai Kertanegara

Haryanto, 1995. Pemanenan Hasil Hutan/ Buku 3 penyaradan. Yayasan Pembinaan Fakultas Kehutanan Universitas Gajah Mada. Yogyakarta.

http.file://D//E-Learning/Pemanenan\%20hasil\%20Hutan/Textbook.html 5/8/2007 3:03:58 PM.

Juta, E.H.P. 1954. Pemungutan hasil Hutan. Timun Mas N.V. Bogor.

Ruslim, Y. 2011. Penerapan Reduced Impact Logging Menggunakan Monokabel Si stem (Pancang Tarik)

Sanyoto, 1976. Penyelidikan Waktu Kerja Elementer. Yayasan Pembinaan Fahutan UGM. Jokjakarta.

Wignjosoebroto, (1989). Teknik Tata Cara dan Pengukuran Kerja. ITS Surabaya 